\title{
INTEGRATED REPORTING DAN KEPUTUSAN INVESTASI: PRINSIP KONEKTIVITAS DAN TIME HORIZON INVESTASI
}

\author{
Murdiyati Dewi \\ murdiyati-d@feb.unair.ac.id \\ Dian Agustia \\ Ardianto \\ Fakultas Ekonomi dan Bisnis Universitas Airlangga
}

\begin{abstract}
An integrated report is a report which contains financial and non-financial information to communicate value creation process by a company. One of the main principles in integrated reporting is connectivity. Using an experimental factorial design of $2 x 2$, this study aims to investigate the effect of connectivity in integrated reporting to support investment decisions by non-professional investors. The non-professional investors are surrogated by 87 accounting undergraduate students. In addition, the study also discusses the effect of time horizons and the interaction between connectivity and time horizonon investment decisions. Investment decision is measured bytotal investment in monetary units. Case material is adopted from the International Integrated Reporting Council with some modifications in diagrams which illustrate information and capital connectivity. Hypotheses are tested using ANOVA and the effects of treatment are examined by performimg post hoc tests. The results show that non-professional investors with high connectivity in integrated report have higher investment decisions than those with low connectivity. In contrast, non-professional investors with integrated reports of high connectivity and long-term investments decide the amount of investment is greater than nonprofessional investors with integrated reports of low connectivity and short-term investments, is not supported.
\end{abstract}

Key words: integration reporting; connectivity; investment time horizon; investment decision

\section{ABSTRAK}

Pelaporan terintegrasi adalah laporan yang berisi informasi keuangan dan non-keuangan yang mengkomunikasikan proses penciptaan nilai oleh perusahaan. Salah satu prinsip utama pelaporan terintegrasi adalah prinsip konektivitas. Penelitian ini bertujuan menguji pengaruh konektivitas dan time horizon investasi terhadap keputusan jumlah investasi. Penelitian ini menggunakan pendekatan eksperimen dengan desain faktorial $2 \times 2$ dengan responden 87 mahasiswa S1 akuntansi sebagai surrogate investor non profesional. Material kasus adalah bagian laporan terintegrasi salah satu perusahaan dalam database International Integrated Reporting Council, dengan modifkasi dalam bentuk diagram yang menggambarkan konektivitas informasi dan modal. Hipotesa diuji dengan ANOVA dan efek dari perlakuan dengan uji post hoc. Hasil menunjukkan bahwa investor non profesional dengan laporan terintegrasi berkonektivitas tinggi memiliki keputusan jumlah investasi lebih besar dari investor non profesional dengan laporan terintegrasi berkonektivitas rendah. Sebaliknya, investor non-profesional dengan laporan terintegrasi berkonektivitas tinggi dan investasi jangka panjang memutuskan jumlah investasi lebih besar dari investor non-profesional dengan laporan terintegrasi berkonektivitas rendah dan investasi jangka pendek, adalah tidak didukung. Hasil penelitian menunjukkan prinsip konektivitas dapat meningkatkan kemanfaatan keputusan dari laporan terintegrasi.

Kata kunci: pelaporan terintegrasi; prinsip konektivitas; time horizon investasi; keputusan investasi.

\section{PENDAHULUAN}

Pelaporan terintegrasi (integrated reporting untuk selanjutnya disimbolkan dengan
$<$ IR $>$ adalah paradigma baru sistem pelaporan perusahaan yang mengintegrasikan informasi keuangan dan informasi non 
keuangan dalam satu laporan (Eccles dan Krzus, 2010). Pelaporan terintegrasi bersifat holistik, strategik, responsif, material, dan relevan di berbagai kerangka waktu (Adams dan Simnett, 2011). Pelaporan terintegrasi diharapkan dapat memperbaiki kualitas informasi yang tersedia untuk penyedia modal keuangan, merupakan pendekatan yang lebih kohesif dan efisien, meningkatkan akuntabilitas dan stewardship, mendukung pemikiran terintegrasi, pengambilan keputusan, dan tindakan yang fokus pada penciptaan nilai dalam jangka pendek, menengah, dan panjang (IIRC, 2013).

Selama kurang lebih tujuh belas tahun perjalanan wacana dan praktik pelaporan terintegrasi, dan enam tahun setelah diterbitkannya Kerangka Internasional Pelaporan Terintegrasi oleh IIRC (International Integrated Reporting Council) pada Desember 2013, praktik <IR> berkembang cepat dan banyak diadopsi diberbagai negara. Visi IIRC untuk menjadikan <IR> sebagai pelaporan wajib dan berlaku global masih perlu perjalanan panjang. Praktek $<\mathrm{IR}>\mathrm{di}$ beberapa negara masih terdapat kesenja ngan yang lebar dalam kualitas laporan terintegrasi diukur dengan kepatuhan pengungkapan $<\mathrm{IR}>$ dengan Kerangka Internasional $<$ IR $>$ dalam hal prinsip $<$ IR $>$ dan elemen konten (Eccles et al., 2019). Gambaran praktek $<$ IR $>$ di Indonesia berdasarkan survey yang dilakukan Adhariani dan de Villiers (2019), diketahui bahwa pengetahuan tentang <IR $>$ di Indonesia masih rendah, dan para penyaji laporan (reporter) enggan untuk mengimplementasikan $<\mathrm{IR}>$ walaupun mereka mengklaim bahwa $<\mathrm{IR}>$ bermanfaat. Penyebab kesenjangan praktek $<$ IR $>$ yang dapat diidentifikasi dari penelitian <IR>antara lain karena tidak adanya standar pelaporan terintegrasi yang berterima umum (Eccles et al., 2019), hanya sedikit perusahaan yang menerapkan konsep, prinsip, dan elemen informasi <IR $>$ secara lengkap (Dumay et al., 2017; Rivera-Arrubla et al., 2017), perusahaan belum menginternalisasi prinsip-prinsip <IR> (Gunarathne dan Senaratne, 2017), kurangnya konektivitas dan proses integrasi dalam organisasi (Adhariani dan de Villiers, 2019), tidak adanya kejelasan definisi dan artikulasi dari konsep pemikiran terintegrasi (Feng et al., 2017), adanya sudut pandang yang berbeda dalam pemahaman dan praktek pengembangan <IR> (Dumay et al., 2017; Silvestri et al., 2017).

Silvestri et al. (2017) mengidentifikasi literatur dan penelitian $<\mathrm{IR}>$ ke dalam dua sudut pandang. Sudut pandang pertama menganggap laporan terintegrasi sebagai evolusi dari laporan tahunan (annual report), dan merupakan sarana komunikasi yang ringkas tentang bagaimana suatu organisasi menciptakan nilai dalam jangka pendek, menengah dan panjang, dengan fokus pada kebutuhan informasi bagi penyedia modal keuangan. Kerangka kerja internasional $<$ IR> (IIRC, 2013), menggunakan sudut pandang ini, dan memiliki retorika menjadikan laporan terintegrasi bersifat wajib (mandatory) dan berlaku secara global. Sudut pandang kedua, menganggap laporan terintegrasi sebagai evolusi dari laporan keberlanjutan (sustainability report), dan menganggap <IR> sebagai sarana perusahaan untuk menyesuaikan praktik bisnis terhadap meningkatnya kesadaran masyarakat akan lingkungan, sosial dan masalah tata kelola atau lebih dikenal dengan Environment, Social, and Government (ESG), seperti yang dinyatakan dalam Global Reporting Initiative (GRI) (GRI, 2013). Sudut pandang ini lebih mengembangkan <IR> sebagai laporan kepada semua pemangku kepentingan perusahaan, dan bersifat sukarela (voluntary).

Pelaporan terintegrasi sebagai bentuk pelaporan wajib dimasa depan perlu dikaji secara terus menerus kebermanfaatannya bagi para pengguna, khususnya investor sebagai pengguna utama. Bukti empiris menunjukkan bahwa sangat sedikit investor yang menggunakan laporan terintegrasi sebagai informasi utama dalam pengambilan keputusan investasi (Rensburg dan Botha, 2014; Slack dan Tsalavoutas, 2018). Slack 
dan Tsalavoutas (2018) menyatakan penyebab kurang digunakannya laporan terintegrasi adalah karena dukungan institusional hanya simbolis, desain dari rerangka pelaporan yang sulit untuk diterapkan, dan budaya pasar modal yang berorientasi jangka pendek.

Sebaliknya, bukti empiris menunjukkan kegunaan dari $<$ IR $>$ antara lain: meningkatkan legitimasi (Camilleri, 2017), meningkatkan nilai perusahaan (Lee dan Yeo, 2016), meningatkan relevansi nilai angka akuntansi berupa peningkatan koefisien nilai pendapatan (Baboukardos dan Rimmel, 2016), mengurangi biaya agensi (Pavlopoulos et al., 2017), mengurangi asimetri informasi (García-Sánchez dan NogueraGámez, 2017), meningkatkan tingkat akurasi prediksi arus kas masa depan (Barth $e$ t al., 2016; Bernardi dan Stark, 2018), meningkatkan efisiensi investasi (Barth et al., 2016), mengurangi tingkat kesalahan peramalan oleh analis (Zhou et al., 2017), dan mengurangi biaya modal ekuitas (Zhou et al., 2017).

Studi pasar modal tentang <IR $>$ oleh Zhou et al. (2017) menunjukkan bahwa ketika kualitas <IR> tinggi, dalam hal ini diukur dengan tingkat kesesuaian <IR> dengan kerangka konseptual internasional $<\mathrm{IR}>$, akan menurangi tingkat kesalahan peramalan (forecast error), namun untuk hubungan antara kualitas <IR> dengan tingkat kesenjangan peramalan (forecast dispersion) tidak terbukti. Hal ini bisa disebabkan karena skor rata-rata konektivitas $<\mathrm{IR}>$ masih sangat rendah dan tidak memiliki variasi karena masih pada tahap awal praktik <IR>, serta adanya keterbatasan kognisi analis dalam memproses informasi dan kompleksitas tugas. Konektivitas (connectivity) informasi adalah prinsip penting dari pemikiran terintegrasi dan laporan terintegrasi, namun merupakan prinsip $<$ IR $>$ yang paling sedikit dipahami dan implementasi konektivitas dalam <IR> masih rendah seperti yang diinformasikan dalam laporan IIRC tentang fase terobosan (breakthrough) 2014-2017, yang kemudian ditegaskan perlunya penelitian terkait konektivitas <IR> (IIRC, 2017).

Tujuan penelitian ini adalah pertama untuk menguji pengaruh konektivitas informasi <IR> terhadap keputusan jumlah investasi oleh investor non profesional. Kedua, untuk menguji pengaruh time horizon investasi (jangka pendek dan jangka panjang) dalam hubungan antara konektivitas informasi dan keputusan jumlah investasi oleh investor non profesional. Metode penelitian yang digunakan adalah metode eksperimen.

Penelitian ini dimotivasi oleh pertama, masih menjadi pro dan kontra tentang $<$ IR $>$ wajib atau sukarela secara global, sehingga masih diperlukan kajian tentang kemanfaatannya bagi pengambilan keputusan; kedua, implementasi konektivitas <IR> masih rendah (IIRC, 2017; Zhou et al., 2017); ketiga, menggunakan metode eksperimen untuk melengkapi penelitian metode archaival yang telah banyak dilakukan oleh peneliti <IR> sebelumnya, dan menekankan kekuatan dari metode eksperimen untuk menguji prinsip konektvitas yang masih rendah penerapannya dalam praktek $\langle\mathrm{IR}\rangle$; keempat, menindaklanjuti review atas penelitian-penelitian <IR> yang dilakukan oleh (Rinaldi et al., 2018; Velte dan Stawinoga, 2017; Villiers et al., 2016) tentang diperlukan penelitian dengan fokus individu dengan menekankan pada metode eksperimen untuk menguji reaksi investor atas $<$ IR>. Hasil penelitian menunjukkan bahwa konektivitas $<$ IR $>$ berpengaruh positif pada keputusan jumlah investasi yang dilakukan oleh investor non profesional. Lebih lanjut, hipotesis terkait pengaruh time horizon investasi panjang (pendek) terhadap hubungan antara konektivitas <IR> tinggi (rendah) dan keputusan jumlah investasi tidak terdukung secara statistik.

\section{TINJAUAN TEORETIS}

Teori kebermanfaatan-keputusan (decision-usefulness theory) menegaskan bahwa laporan keuangan sebagai hasil dari proses akuntansi harus memiliki asas keber- 
manfaatan-keputusan bagi pengguna. Konsep akuntansi pendapatan yang dikenalkan oleh Staubus pada 1955 merupakan asal usul decision-usefulness theory (Staubus, 2010). Dua hal yang diperlukan untuk menjamin manfaat dari suatu laporan perusahaan, yaitu identifikasi pengguna dan jenis laporan yang dibutuhkan serta masalah dalam pengambilan keputusan. Menurut teori kebermanfaatan-keputusan, investor akan bereaksi ke arah yang diprediksi ketika informasi positif atau negatif dilaporkan, mengingat bahwa informasi ini dianggap relevan dengan nilai (Staubus, 2013).

Laporan terintegrasi sebagai perkembangan dari laporan keuangan, merupakan bukti bahwa terjadi pergeseran definisi manfaat dari laporan keuangan. Perusahaan kini dituntut untuk memberikan informasi yang lebih luas karena terjadi perubahan paradigma pengelolaan bisnis menuju ke sustainability development. Menurut IIRC (2013), <IR> memiliki kosep mendasar yaitu mengkomunikasikan pemikiran terintegrasi perusahaan dalam proses penciptaan nilai jangka pendek, menengah, maupun jangka panjang, dengan keenam jenis modalnya yaitu modal keuangan, modal manufaktur, modal intelektual, modal manusia, modal sosial dan relasi, dan modal alam oleh perusahaan. Komunikasi tersebut harus tercermin dalam isi elemen-elemen yang terdapat dalam $<\mathrm{IR}>$ berupa organisasi dan lingkungan eksternal, tata kelola, model bisnis, resiko dan peluang, strategi dan alokasi modal, kinerja keuangan dan non keuangan perusahaan, outlook, dan basis penyajian. Selanjutnya, perusahaan dalam menyusun $<$ IR $>$ harus memperhatikan prinsip dasar berupa fokus pada strategi dan orientasi masa depan, konektivitas informasi, hubungan stakeholders, materialitas, ringkas, andal dan lengkap, serta konsisten dan dapat diperbandingkan. Prinsip konektivitas $<\mathrm{IR}>$ menekankan bahwa hubungan diantara elemen-elemen kunci dalam <IR> harus disajikan dan diartikulasikan dengan jelas, menunjukkan adanya konektivitas antar waktu, menginformasikan saling ketergantungan dan trade off antar sumber daya, adanya konektivitas antara informasi keuangan dan informasi lain, adanya konektivitas antara informasi kuantitatif dan kualitatif, adanya konektivitas antara informasi manajemen, dewan direksi, dan pihak eksternal, serta adanya konektivitas informasi <IR> dengan komunikasi informasi dari perusahaan lain dan komunikasi informasi dari sumber lain, sehingga dapat memberikan gambaran yang lebih holistik tentang penciptaan nilai oleh perusahaan (IIRC, 2013). Konektivitas informasi dan manfaat secara keseluruhan dari <IR> meningkat ketika disajikan dalam struktur yang logis, jelas dalam penyampaian dan pilihan bahasanya termasuk penggunaan petunjuk-petunjuk yang tepat (navigation devices). Haji dan Anifowose (2016) menyatakan ada peningkatan signifikan atas tingkat dan kualitas praktik <IR $>$ di Afrika Selatan, yaitu peningkatan konektivitas informasi dalam $<I R>$, peningkatan kualitas proses penentuan materialitas, dan keandalan serta kelengkapan $<\mathrm{IR}>$.

Konsep human information processing dari Libby dan Lewis (1977) menunjukkan bahwa dalam proses pengambilan keputusan melibatkan input, proses dan output. Input berupa informasi atau variabel penting lainnya yang berpengaruh dalam proses pengambilan keputusan, antara lain berupa skala karakteristik individual, propertis statistik dari set informasi, konten informasi, metode penyajian dan konteks. Variabel penelitian yang terkait dengan proses pengambilan keputusan, dapat berupa karakteristik pengambil keputusan, atau karakteristik dari aturan keputusan. Sedangkan variabel yang terkait output adalah berupa penilaian, prediksi, dan keputusan, dengan variabel yang diamati dapat berupa kualitas penilaian atau kualitas keputusan dan wawasan diri (selfinsight).

Review atas penelitian perilaku dalam akuntansi keuangan yang terbit selama tahun 1990-1999 yang dilakukan oleh 
McEwen dan Welsh (2001) yang berfokus pada aspek kebermanfaatan dari informasi akuntansi menunjukkan hasil yang tidak konsisten bahkan kontradiksi. Ada dasar teori yang kuat untuk mempertimbangkan peran perilaku individu dalam menjelaskan ketidakmampuan untuk menggunakan informasi akuntansi untuk memprediksi pendapatan dan arus kas secara akurat. Bias pada pengambilan keputusan dapat di sebabkan karena bias persepsi atas informasi yang ada, bias memori, bias integrasiinformasi dari berbagai sumber, bias kriteria judgment, dan bias motivasional.

Arnold et al. (2018) dalam studinya fokus melihat reaksi investor terhadap informasi non-keuangan. Studi ini menggunakan responden investor profesional untuk menguji timing effect ketika laporan keuangan dan laporan non-keuangan disajikan secara terpisah. Hasil studi menunjukkan bahwa memang terjadi efek bias persepsi, yaitu efekanchoring terhadap laporan keuangan ketika laporan keuangan disajikan tidak bersama-sama dengan laporan non-keuangan. Hasil studi lebih lanjut mendukung argumen penyajian laporan keuangan dan laporan non-keuangan secara bersama-sama dalam bentuk laporan terintegrasi untuk meningkatkan kualitas keputusan investasi.

Cheng et al. (2014) dalam studinya menguji relevansi dan assurance informasi sustainability terhadap strategi perusahaan dalam hubungannya dengan pengambilan keputusan investor non-profesional. Desain eksperimen pertamanya, menguji pengaruh tingkat relevansi tinggi dan rendah dari laporan environmental, social, and governance (ESG) terhadap dua tipe strategi yaitu diferensiasi dan cost-leadership. Desain eksperimen yang kedua menguji kesesuaian ESG indikator terhadap strategi. Hasil studi dari kedua desain eksperimen tersebut menunjukkan investor menilai indikator ESG lebih penting dan menjadi pendorong investasi pada perusahaan dimana indikator ESG nya memiliki relevansi dengan strategi perusahaan. Eksperimen pertama juga memberikan bukti bahwa keberadaan assurance meningkatkan keinginan berinvestasi lebih besar ketika ESG indikator menunjukkan relevansi terhadap strategi perusahaan.

Terkait dengan manfaat IR bagi pengguna laporan, Serafeim (2015) meneliti hubungan antara <IR> dan tipe investor. Tipe investor dibedakan menjadi investor jangka panjang dan investor jangka pendek. Hasil studi menunjukkan bahwa perusahaan yang menyajikan $<$ IR $>$ memiliki investor dengan fokus jangka panjang dan lebih berdedikasi dalam jumlah yang lebih banyak dibandingkan dengan perusahaan yang tidak menyajikan $<$ IR $>$.

\section{Pengembangan Hipotesis}

Penelitian decision usefullnes theory dengan fokus laporan terintegrasi menggunakan wawancara, menunjukkan bahwa <IR> memiliki kebermanfaatan-keputusan karena menunjukkan adanya keterkaitan penciptaan nilai dengan strategi perusahaan, pelaporan indikator kinerja utama yang mencerminkan strategi dan bisnis inti, keterkaitan risiko dengan penciptaan nilai dan modal yang relevan dalam bisnis (Slack dan Tsalavoutas, 2018).Informasi keuangan akan lebih bermanfaat jika dilengkapi oleh informasi non-keuangan, selanjutnya akan lebih mempengaruhi kesediaan untuk berinvestasi jika informasi yang ada menunjukkan relevansi antara strategi perusahaan dan indikator kinerja utama, dalam hal ini menguji laporan ESG (Cheng et al., 2014).

Bagian dari hasil penelitian Dong (2017) menyatakan bahwa ketika kinerja keuangan di kontrol, investor akan berinvestasi lebih besar jika kinerja non keuangan disajikan terhubung secara kausal (causally linked) daripada ketika kinerja non keuangan disajikan secara tidak terhubung secara kausal. Uji mediasi pengaruh causal linked terhadap keputusan investasi melalui variabel relevansi informasi non-keuangan menunjukkan hasil positif. Causal linked menunjukkan bahwa antar informasi saling terkoneksi dalam cara penyajian dan juga 
terkoneksi dalam isi sehingga ada relevansi antar elemen.

Semakin terkoneksi informasi akan membuat informasi lebih mudah terbaca (readability), selain itu waktu serta biaya ataupun usaha (effort) yang dibutuhkan untuk memproses informasi menjadi lebih kecil, dan respon akan sesuai dengan kandungan informasi tersebut apakah positif atau negatif, atau good news atau bad news. Jika keputusan sesuai dengan prediksi kandungan informasi maka laporan atau informasi memiliki kegunaan keputusan yang baik.

$\mathrm{H}_{1}$ : Investor non profesional yang menerima laporan terintegrasi dengan konektivitas tinggi, memutuskan jumlah investasi yang lebih besar dari pada investor non profesional yang menerima laporan terintegrasi dengan konektivitas rendah.

Manfaat $<\mathrm{IR}>$ dirasakan berbeda untuk time horizon investasi yang berbeda. Serafeim (2015) dalam studinya mejelaskan bahwa investor jangka panjang dan berdedikasi lebih mengapresiasi <IR> dibandingkan investor dengan fokus jangka pendek. Hal tersebut logis karena konten <IR $>$ yang memang tidak hanya fokus pada pelaporan yang sifatnya historis namun juga forwardlooking sesuai dengan kebutuhan investor jangka panjang.

Dong (2017), menguji tentang kepercayaan terhadap pengungkapan informasi non keuangan terhadap keputusan investasi, dengan melihat faktor input dan faktor proses, meliputi pengalaman investasi, time horizon investasi, format pengungkapan, dan proses kognisi, yang diprediksi mempengaruhi keputusan investor. Dong (2017) menyatakan bahwa pengungkapan informasi non keuangan, lebih mempengaruhi investor jangka panjang dari pada investor jangka pendek, dan juga lebih mempengaruhi investor dengan pengalaman tinggi dari pada investor yang kurang berpengalaman. Selanjutnya ketika mengharus- kan peserta untuk mengevaluasi kinerja perusahaan secara terpisah berdasarkan ukuran keuangan dan non-keuangan, atau hanya menyajikan informasi non keuangan dalam format yang lebih mudah dibaca, tidak secara signifikan mengubah ketergantungan pada pengungkapan non finansial untuk investor dengan pengalaman rendah dan investor jangka pendek. Namun, ketika kedua intervensi tersebut dilaksanakan secara bersamaan, informasi non-keuangan secara signifikan mempengaruhi jumlah yang diinvestasikan oleh para investor tersebut.

$\mathrm{H}_{2}$ : Investor non profesional yang menerima laporan terintegrasi dengan konektivitas tinggi dan time horizon investasi panjang, memutuskan jumlah investasi yang lebih besar dari pada investor non profesional yang menerima laporan terintegrasi dengan konektivitas rendah dan timehorizon investasi pendek.

\section{METODE PENELITIAN Desain Eksperimen}

Penelitian ini menggunakan metode eksperimen, dengan desain faktorial $2 \times 2$ dan bersifat antar subyek (between subject). Faktor dalam eksperimen ini ialah konektivitas <IR > dengan dua level yaitu konektivitas tinggi dan konektivitas rendah, serta faktor time horizon investasi dengan dua level yaitu jangka pedek dan jangka panjang. Setiap peserta dalam eksperimen hanya akan memperoleh satu kondisi tertentu, yang ditentukan secara acak.

\section{Partisipan}

Partisipan dalam eksperimenadalah 87 mahasiswa Program Sarjana Akuntansi Fakultas Ekonomi dan Bisnis Universitas Airlangga, untuk berperan sebagai potensial investor non profesional. Partisipan adalah mahasiswa semester enam keatas dan telah menempuh mata kuliah akuntansi keuangan dan akuntansi manajemen atau manajemen strategis, dengan pertimbangan parti- 
sipan telah memiliki kemampuan menganalisis laporan keuangan, strategi perusahaan, dan indikator kinerja keuangan dan non keuangan, untuk pengambilan keputusan investasi. Mahasiswa akuntansi sebagai pengganti (surrogate) investor non profesional dalam tugas keputusan investasi, memiliki keputusan yang sama baiknya dengan partisipan yang berasal dari praktisioner (Liyanarachchi, 2007).

\section{Variabel Penelitian}

Variabel dependen dalam eksperimen ini adalah keputusan investasi oleh investor non professional, yang berupa jumlah investasi. Pengukuran variabel dependen, memodifikasi Dong (2017), berupa besaran rupiah yang akan diinvestasikan dalam perusahaan target dari dana sebesar $\mathrm{Rp}$ 10.000.000 yang disediakan, dengan ketentuan keputusan jumlah investasi dinyatakan dalam kelipatan Rp500.000.

Variabel independen pertama adalah konektivitas laporan terintegrasi, dimanipulasi pada dua level yaitu laporan terintegrasi dengan konektivitas tinggi dan laporan terintegrasi dengan tingkat konektivitas rendah. Kondisi $<\mathrm{IR}>$ dengan tingkat konektivitas tinggi, yaitu (1) informasi strategi perusahaan disajikan secara disaggregate, dengan disajikan per bidang, (2) informasi bisnis model disajikan dengan diagram yang menunjukkan saling keterkaitan antar informasi dan antar modal, (3) informasi indikator kinerja ditambahkan juga data target atau masa depan dan data indikator rata-rata industri, yang menunjukkan informasi terkoneksi dengan data perencanaan, dan data eksternal. Sebaliknya kondisi <IR> dengan konektivitas rendah ialah informasi strategi, dan enam jenis modal disajikan secara agregat dan sesuai abjad, serta indikator kinerja disajikan tanpa dibandingkan dengan target masa depan dan rata-rata industri. Manipulasi dengan menggunakan diagram pada satu kondisi dan disajikan sesuai abjad pada kondisi lainnya diinspirasi oleh penelitian Green dan Cheng (2019).
Variabel independen kedua adalah time horizon investasi, yaitu jangka waktu investor akan menahan investasi tersebut untuk tidak menjualnya, dimanipulasi pada dua level yaitu investasi jangka pendek, dan investasi jangka panjang (Dong, 2017).

\section{Material Kasus dan Prosedur Eksperimen}

Material kasus terdiri dari 3 (tiga) bagian. Bagian 1 berupa instruksi umum, dan informasi tentang perusahaan target, meliputi strategi, bisnis model, indikator keuangan dan non keuangan, dan laporan keuangan, bagian 2 berisi pertanyaan yang menggambarkan keputusan investasi, sedangkan bagian 3 berisi pertanyaan untuk tujuan manipulasi cek, dan demografi partisipan. Bagian 3 hanya boleh dibaca dan dijawab setelah bagian 2 diselesaikan dan dikumpulkan. Setiap partisipan menerima material kasus dengan 1 kondisi secara acak dari 4 kondisi berikut, yaitu kelompok konektivitas <IR> rendah dan time horizon pendek (selanjutnya disingkat Kr-Tpd), konektivitas $<\mathrm{IR}>$ rendah dan time horizon panjang (selanjutnya disingkat $\mathrm{Kr}-\mathrm{Tpj}$ ), konektivitas <IR $>$ tinggi dan time horizon pendek (selanjutnya disingkat Kt-Tpd), dan konektivitas <IR> tinggi dan timehorizon panjang (selanjutnya disingkat Kt-Tpj).

Partisipan diminta membaca dan menganalisa informasi terkait perusahaan target yang diterima dan berdasarkan penilaian dan analisa tersebut, selanjutnya partisipan diminta melakukan keputusan investasi. Perusahaan kasus secara umum berada dalam konteks kinerja yang positif, terutama pada kinerja non keuangan.

\section{Validasi Material Kasus, Validitas Eko- logis dan Pilot Test}

Materi kasus dan instrumen penelitian divalidasi melalui diskusi dengan akademisi yang berkompeten, sehingga diperoleh keyakinan bahwa materi kasus dapat menunjukkan hubungan kausalitas antar variabel penelitian. Instrumen yang telah didiskusikan, dilakukan uji dengan melakukan pilot-test untuk memastikan manipulasi 
telah dipahami. Pada pilot test dilakukan juga pengujian awal atas kemampuan partisipan menganalisis laporan keuangan dan pemahaman terhadap indikator kinerja keuangan dan non keuangan, sehingga memastikan kriteria sampel sesuai dengan tujuan ekperimen.

Pilot test dilakukan pada 26 mahasiswa magister akuntansi dan 33 mahasiswa program sarjana akuntansi. Hasil test kemampuan menunjukkan skor cukup yaitu sekitar 60, dan rata-rata skor mahasiswa magister akuntansi maupun mahasiswa program sarjana akuntansi relatif sama. Hasil test terkait perlakuan atau manipulasi, disimpulkan bahwa manipulasi tidak dipahami oleh partisipan dengan baik, dan partisipan tidak sungguh-sungguh mengerjakan kasus karena sebagian besar partisipan tidak lolos menjawab 2 (dua) pertanyaan yang bersifat cek manipulasi. Tingkat kegagalan untuk manipulasi konektivitas sebesar 46 persen, dan manipulasi time horizon 27 persen. Langkah selanjutnya yaitu memperbaiki material kasus dengan melakukan diskusi ulang dengan akademisi.

Perbaikan dilakukan dengan menyederhanakan kasus hanya meliputi strategi, model bisnis, indikator utama keuangan dan non keuangan, dan laporan keuangan, serta informasi umum industri. Perbaikan juga dilakukan pada butir pertanyaan cek manipulasi, dengan mengajukan pertanyaan yang tidak ambigu atau multiarti. Pilot test kedua menunjukkan hasil $90 \%$ partisipan lolos uji cek manipulasi, dan diputuskan materi kasus siap digunakan untuk eksperimen.

Faktor-faktor pengancam validitas internal dari desain grup multipel seperti seleksi, interaksi seleksi-histori, interaksi seleksi-maturasi, interaksi seleksi-testing, interaksi seleksi-instrumentasi, interaksi seleksi-mortalitas, interaksi seleksi-regresi statistis (Nahartyo, 2012) telah diupayakan dalam desain eksperimen laboratorium ini yaitu dengan (1) partisipan memiliki karakteristik yang ekuivalen dan ditempatkan dalam kelompok secara acak, (2) pelaksana- an eksperimen pada semua kelompok dilakukan secara bersamaan di waktu dan tempat yang ideal yaitu jam 10.00, dan ruang yang nyaman, serta posisi tempat duduk yang cukup berjarak antar partisipan, sehingga partisipan dalam kondisi segar, tidak saling bekerjasama dan tidak terganggu faktor lain, (3) material kasus disederhanakan hanya pada informasi tertentu sehingga waktu penyelesaian tugas berkisar 30-45 menit, berdasar hasil pilot test.

Validitas ekologis, sebagai salah satu perspektif validitas eksternal adalah bahwa penelitian dilakukan dengan situasi yang menyerupai kenyataan atau kondisi yang realistis, sehingga hasil penelitian dapat digeneralisasi ke lingkungan alamiah (Nahartyo, 2012). Laporan terintegrasi yang digunakan sebagai acuan adalah laporan terintegrasi perusahaan dibidang pertambangan, yang diambil dari best pactice di website IIRC, dengan kategori connectivity baik.

Partisipan juga dimintai pendapat, tentang realistis tidaknya kasus yang diterima, dan respon partisipan menunjukkan nilai yang relatif cukup yaitu sebesar 7 dalam skala 10.

\section{Metode Analisis}

Penelitian ini memiliki dua variabel independen yang bersifat kategorikal, yaitu konektivitas <IR> dan time horizon investasi, dan variabel dependen yang berskala numerik yaitu jumlah investasi sebagai konstruk dari keputusan investasi. Pengujian hipotesa dalam eksperimen ini menggunakan uji ANOVA dengan menganalisis varian. Pengujian ANOVA digunakan untuk menguji efek utama yaitu mengetahui pengaruh masing-masing perlakuan atau variabel independen terhadap variabel dependen, dan juga menguji efek interaksi antar perlakuan atau antar variabel independen terhadap variabel dependen. Pengujian lebih rinci adalah dengan analisis Post Hoc, dan untuk uji kontras mean digunakan uji Tukey Kramer atau Scheffe dalam eksperimen ini karena memiliki jumlah anggota 
yang tidak sama pada masing masing kelompok perlakuan. Pengujian asumsi yang harus terpenuhi sebelum menguji hipotesa adalah; pertama menguji bahwa prosedur randomisasi dalam eksperimen berjalan efektif, yaitu memastikan bahwa setiap kelompok perlakuan tidak memiliki perbedaan signifikan dalam hal demografi partisipan, yang meliputi usia, jenis kelamin dan pengalaman kerja. Selanjutnya dilakukan pengujian asumsi dasar uji ANOVA, yaitu asumsi bahwa variabel dependen memiliki kesalahan variansi yang sama untuk semua kelompok perlakuan (equality of variance), dan digunakan uji homogenitas varian dengan Levene's test.

\section{ANALISIS DAN PEMBAHASAN}

\section{Cek Manipulasi dan Uji Asumsi}

Mahasiswa program sarjana akuntansi yang berpartisipasi dalam eksperimen berjumlah 114 orang terdiri dari 37 laki-laki dan 77 perempuan dan secara random di bagi dalam empat group perlakuan. Berdasarkan pemeriksaan awal, terkait kriteria partisipan dan cek manipulasi dengan 2 pertanyaan, yaitu "berdasar materi kasus yang saudara terima, berapa lama saudara akan memiliki saham ini?" dan pertanyaan berikutnya"apakah materi kasus yang saudara trima memiliki link ke lampiran?", 27 partisipan gagal, sehingga yang disertakan dalam uji hipotesa sebanyak 87 partisipan.
Pengujian randomisasi dilakukan se- belum pengujian hipotesis dengan tujuan memastikan bahwa tiap-tiap kelompok tidak menunjukkan varian yang disebabkan kondisi demografi subyek. Pengujian dilakukan dengan Uji ANOVA, untuk menentukan apakah rata-rata kelompok perlakuan menunjukkan perbedaan secara nyata. Hasil uji perbedaan karakteristik individu dapat dilihat pada Tabel 1. Analisis ini memiliki asumsi bahwa kelompok yang dianalisis memiliki varian yang sama. Hasil pengujian menunjukkan statistik uji $\mathrm{F}$ untuk umur subyek adalah 1,026 dengan $\mathrm{p}$ sebesar 0,385, nilai statistik uji $\mathrm{F}$ untuk jenis kelamin subyek adalah 0,277 dengan $p$ sebesar 0,842, dan nilai statistik uji $\mathrm{F}$ untuk pengalaman kerja subyek sebesar 0,402 dengan $p$ sebesar 0,752. Kesimpulan dari uji ini adalah bahwa tidak ada perbedaan signifikan antar kelompok perlakuan, sehingga randomisasi berjalan baik. Pengujian asumsi berikutnya adalah pengujian homogenitas varian dari variabel dependen, yang diuji dengan menggunakan Levene's test. Hasil uji levene's (Tabel 2), menunjukkan $\mathrm{F}$ sebesar 1,964 dengan $p$ sebesar 0,126 (tidak signifikan pada tingkat signifikansi 0,05). Berdasarkan hasil uji ini tidak ada alasan untuk menolak hipotesis null, simpulan asumsi uji ANOVA terpenuhi (Hair et al., 2006).

Tabel 1

Uji Perbedaan karakteristik Individu

\begin{tabular}{llrrrrr}
\hline Karakteristik & Aumlah & $\begin{array}{c}\text { df } \\
\text { Kuadrat }\end{array}$ & $\begin{array}{c}\text { Mean } \\
\text { Kuadrat }\end{array}$ & F & Sig. \\
\hline Umur & Antar Group & 3,085 & 3 & 1,028 & 1,026 & 0,385 \\
& Intra group & 83,145 & 83 & 1,002 & & \\
Jenis Kelamin & Aotal & 86,230 & 86 & & & \\
& Antar Group & 0,188 & 3 & 0,063 & 0,277 & 0,842 \\
& Intra group & 18,801 & 83 & 0,227 & & \\
Pengalaman & Total & 18,989 & 86 & & & \\
Kerja & Antar Group & 0,116 & 3 & 0,039 & 0,402 & 0,752 \\
& Intra group & 7,953 & 83 & 0,096 & & \\
\hline
\end{tabular}


Tabel 2

Test of Homogenity of Variances-Keputusan Jumlah Investasi

\begin{tabular}{cccc}
\hline Levene Statistic & df1 & df2 & Sig. \\
\hline 1,964 & 3 & 83 & 0,126 \\
\hline Sumber: Data diolah & & & \\
\hline
\end{tabular}

\section{Hasil Pengujian Hipotesis}

Hipotesa $1 \quad\left(\mathrm{H}_{1}\right)$ memprediksi bahwa investor non profesional yang menerima laporan terintegrasi dengan konektivitas tinggi, memutuskan jumlah investasi yang lebih besar daripada investor non profesional yang menerima laporan terintegrasi dengan konektivitas rendah. Hasil pengujian hipotesa menggunakan ANOVA dengan variabel dependen jumlah investasi dan variabel independen adalah konektivitas laporan terintegrasi, time horizon investasi, dan interaksi keduanya tersaji pada Tabel 3. Tabel 3 panel A menunjukkan statistik deskriptif jumlah rata-rata investasi. Tabel 3 panel B1 menunjukkan model ANOVA untuk pengujian efek utama dan efek interaksi diantara perlakuan. Hasil pengujian terlihat efek utama (main effect) variabel konektivitas laporan terintegrasi terhadap jumlah investasi memiliki nilai $\mathrm{F}$ sebesar 3,226 dengan p sebesar 0,076 (Tabel 3 panel B1) dan rata-rata jumlah investasi (Tabel 3 panel A) menunjukkan tingkat konektivitas laporan terintegrasi tinggi sebesar Rp5.306.122 dan tingkat konektivitas <IR> rendah adalah sebesar Rp 4.578.947, maka dapat disimpulkan bahwa hipotesa $1\left(\mathrm{H}_{1}\right)$ didukung, pada tingkat signifikansi $10 \%$. Hasil sebaliknya untuk variabel time horizon investasi, menunjukan hasil tidak signifikan secara statistik (dalam eksperimen ini tidak dihipotesakan karena fokus pada prinsip konektivitas). Sedangkan untuk efek interaksi diantara keduanya menunjukkan nilai $\mathrm{F}$ sebesar 3,186 dengan $\mathrm{p}$ sebesar 0,078 yang berarti ada interaksi (tabel 3 panel B1) pada tingkat signifikansi 0,10, dan pada Gambar 1 ( $0=$ time horizon pendek; $1=$ time horizon panjang). Hasil pengujian menunjukkan ada efek interaksi, maka perlu dilakukan analisis lanjutan dengan memodifikasi menjadi variabel independennya adalah kelompok perlakuan, dan tersaji pada Tabel 3 panel B2.

Hipotesa $2\left(\mathrm{H}_{2}\right)$ memprediksi bahwa investor non profesional yang menerima laporan terintegrasi dengan konektivitas tinggi dan time horizon investasi panjang, memutuskan jumlah investasi yang lebih besar daripada investor non profesional yang menerima laporan terintegrasi dengan konektivitas rendah dan time horizon investasi pendek.

Hasil pengujian hipotesa menggunakan ANOVA dengan variabel dependen jumlah investasi dan variabel independen adalah kelompok perlakuan tersaji pada Tabel 3 panel B2 menunjukkan model ANOVA untuk pengujian pengaruh antar subyek, terlihat bahwa hubungan antara variabel dependen jumlah investasi dengan masingmasing kelompok perlakuan memiliki nilai F sebesar 2,181 dengan $p$ sebesar 0,096. Kesimpulan hasil pengujian menunjukkan bahwa rata-rata keputusan jumlah investasi antar kelompok (beween group) dengan ratarata keputusan jumlah investasi dalam kelompok (within group) adalah berbeda, pada tingkat signifikansi 0,10, karena signifikan maka dianalisis lebih lanjut dengan melihat uji post-hoc. Tabel 3 panel $\mathrm{C}$ hasil uji post hoc, menunjukkan bahwa (1) tidak ada perbedaan jumlah investasi yang signifikan antara konektivitas rendah-time horizon pendek (Kr-Tpd) dan konektivitas rendah-time horizon panjang (Kr-Tpj), (2) ada perbedaan jumlah investasi yang signifikan antara konektivitas rendah-time horizon pendek (Kr-Tpd) dan konektivitas tinggi-time horizon pendek (Kt-Tpd), (3) tidak ada perbedaan jumlah investasi yang signifikan antara konektivitas rendah-time horizon pendek (Kr-Tpd) dan konektivitas tinggitime horizon panjang (Kt-Tpj), (4) tidak ada 
Tabel 3

Statistik Deskriptif dan Uji Hipotesa

Jumlah investasi

Panel A: Mean (Standard Deviations)

\begin{tabular}{lccc}
\hline & Time horizon pendek & $\begin{array}{l}\text { Time horizon- } \\
\text { panjang }\end{array}$ & Rata-rata-baris \\
\hline Konektivitas <IR> rendah & $\mathrm{Rp} 4.166 .667$ & $\mathrm{Rp} 4.950 .000$ & $\mathrm{Rp} 4.578 .947$ \\
& $(\mathrm{Rp} 2.300 .895)$ & $(\mathrm{Rp} 2.038 .446)$ & $(\mathrm{Rp} 2.173 .322)$ \\
& $\mathrm{N}=18$ & $\mathrm{~N}=20$ & $\mathrm{~N}=38$ \\
Konektivitas <IR> tinggi & $\mathrm{Rp} 5.592 .593$ & $\mathrm{Rp} 4.954 .545$ & $\mathrm{Rp} 5.306 .122$ \\
& $(\mathrm{Rp} 1.525 .659)$ & $(\mathrm{Rp} 1.550 .031)$ & $(\mathrm{Rp} 1.553 .948)$ \\
& $\mathrm{N}=27$ & $\mathrm{~N}=22$ & $\mathrm{~N}=49$ \\
Rata-rata kolom & $\mathrm{Rp} 5.022 .222$ & $(\mathrm{Rp} 4.952 .381)$ & $\mathrm{Rp} 4.988 .506$ \\
& $(\mathrm{Rp} 1.979 .886)$ & $(\mathrm{Rp} 1.776 .574)$ & $(\mathrm{Rp} 1.873,898)$ \\
& $\mathrm{N}=45$ & $\mathrm{~N}=42$ & $\mathrm{~N}=87$ \\
\hline
\end{tabular}

Panel B1: Tabel ANOVA- Jumlah investasi

\begin{tabular}{lrrrrr}
\hline $\begin{array}{l}\text { Source of } \\
\text { variation }\end{array}$ & Sum of Square & df & Mean Square & F-stat & p-value \\
\hline Konektivitas & 10.881 .571 .459 .145 & 1 & 10.881 .571 .459 .145 & 3,226 & $0,076^{*}$ \\
Time Horizon & 112.248 .868 .874 & 1 & 112.248 .868 .874 & 0,033 & 0,856 \\
$\begin{array}{l}\text { Konektivitas } x \\
\text { Time horizon }\end{array}$ & 10.743 .702 .166 .397 & 1 & 10.743 .702 .166 .397 & 3,186 & $0.078^{*}$ \\
Error & 279923063973064 & 83 & 3.372 .567 .035 .820 & & \\
\hline
\end{tabular}

Panel B2: Tabel ANOVA- Jumlah investasi

\begin{tabular}{llllll}
\hline & Sum of Square & $\mathrm{df}$ & Mean Square & F-stat & p-value \\
\hline Between roups & $2,207 \mathrm{E}+13$ & 3 & $7,355 \mathrm{E}+12$ & 2,181 & $0,096^{*}$ \\
Within Groups & $2,799 \mathrm{E}+14$ & 83 & $3,373 \mathrm{E}+12$ & & \\
& $3,020 \mathrm{E}+14$ & 86 & & & \\
\hline
\end{tabular}

Panel C: Mean Kontras-Post Hoc Tests-Jumlah investasi - Scheefe

\begin{tabular}{llrrl}
\hline (I) Kelompok & (J) Kelompok & Mean Difference (I-J) & Standar Error & Signifikansi \\
\hline Kr-Tpd & Kr-Tpj & $-783.333,33$ & $596.651,646$ & 0,633 \\
\hline & Kt-Tpd & $-1.425 .925,93$ & $558.815,466$ & $0,098^{*}$ \\
\hline Kr-Tpj & Kt-Tpj & $-787.878,79$ & $583.663,719$ & 0,612 \\
\hline & Kt-Tpd & $-642.592,59$ & $541.791,696$ & 0,705 \\
\hline Kt-Tpd & Kt-Tpj & $-4.545,45$ & $567.385,983$ & 1.000 \\
\hline
\end{tabular}

Sumber: Data diolah

perbedaan jumlah investasi yang signifikan antara konektivitas rendah-time horizon panjang (Kr-Tpj) dan konektivitas tinggitime horizon pendek (Kt-Tpd), (5) tidak ada perbedaan jumlah investasi yang signifikan antara konektivitas rendah-time horizon panjang (Kr-Tpj) dan konektivitas tinggitime horizon panjang (Kt-Tpj), (6) tidak ada perbedaan jumlah investasi yang signifikan antara konektivitas tinggi-time horizon pendek (Kt-Tpd) dan konektivitas tinggitime horizon panjang (Kt-Tpj). 


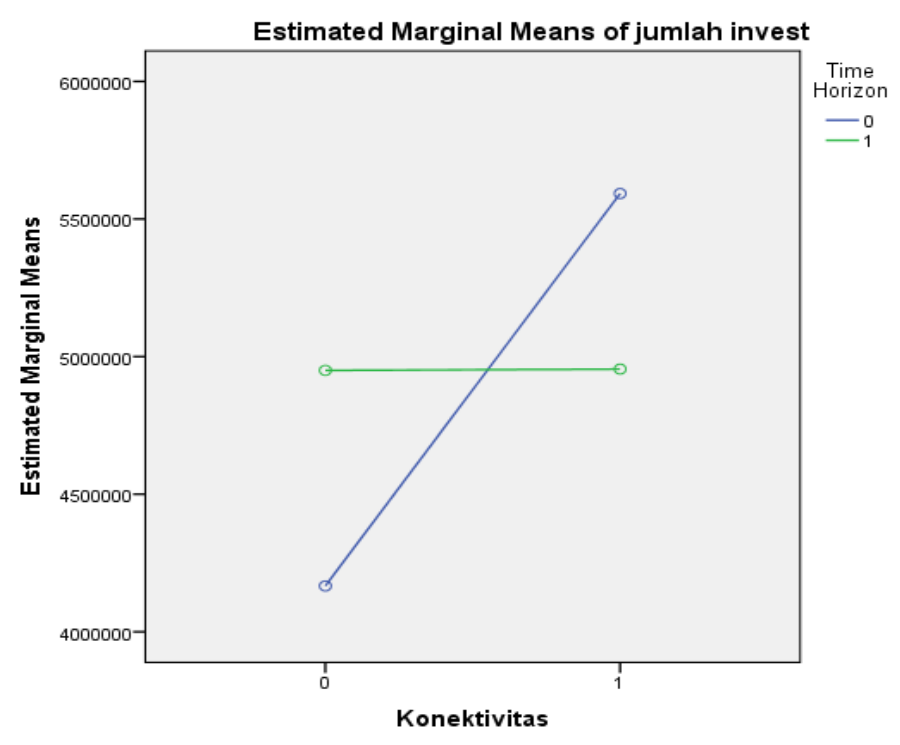

Gambar 1

\section{Jumlah investasi ditinjau berdasarkan konektivitas $<$ IR $>$ dan time horizon investasi}

Berdasarkan Tabel 3 panel $C$, hasil pengujian hipotesa $2\left(\mathrm{H}_{2}\right)$ yaitu membandingkan "Kr-Tpd" (konektivitas rendah-time horizon pendek) dan "Kt-Tpj" (konektivitas tinggi-time horizon panjang), menghasilkan p sebesar 0,612, maka $\mathrm{H}_{2}$ tidak didukung, walaupun rata-rata jumlah investasi kelompok "Kt-Tpj" lebih besar dari kelompok"KrTpd". Berdasar Tabel 3 panel C, terlihat bahwa hasil yang signifikan hanya terjadi ketika membandingkan kelompok "KrTpd" (konektivitas rendah-time horizon pendek) dan "Kt-Tpd" (konektivitas tinggi-time horizon pendek), dan rata-rata jumlah investasi kelompok "Kt-Tpd" lebih besar dari kelompok "Kr-Tpd".

Berdasarkan hasil eksperimen, laporan terintegrasi yang terkoneksi tinggi akan direspon lebih besar oleh investor dalam keputusan jumlah investasi yang dibuat, dan arah keputusan yang seiring dengan yang diprediksikan. Hal ini menunjukkan bahwa laporan terintegrasi yang disajikan dengan koneksi yang tinggi memiliki nilai kebermanfaatan-keputusan yang lebih besar. Konektivitas yang tinggi dalam <IR> akan memberikan gambaran holistik kepada investor bagaimana kombinasi, keterkaitan dan ketergantungan antara faktor- faktor yang mempengaruhi kemampuan organisasi untuk menciptakan nilai dari waktu ke waktu (IIRC, 2013), namun informasi yang tersaji mudah di pahami sehingga meningkatkan tingkat kepercayaan investor. Metode eksperimen mengontrol konteks perusahaan, terbukti bahwa kinerja dalam kondisi yang sama, namun disajikan berbeda, informasi terkoneksi tinggi atau rendah, menghasilkan keputusan yang berbeda, sehingga yakin bahwa konektivitas tinggi dapat memperbaiki kualitas informasi.

Laporan terintegrasi dapat direspon secara berbeda oleh investor non pofesional, karena banyak faktor, antara lain faktor kognisi dalam memproses informasi, dan faktor preferensi. Hasil eksperimen yang menganalisis konektivitas informasi dengan faktor time-horizon investasi masih belum mampu didukung. Konektivitas informasi dalam eksperimen ini hanya bisa efektif hasilnya pada investor dengan time-horizon jangka pendek, argumen yang dapat memperkuat adalah bahwa investor jangka pendek berorientasi jangka pendek, hanya menekankan pada faktor keuangan sesuai dengan perilaku pasar modal, namun jika informasi non keuangan juga tersaji dan 
mudah untuk dianalisis maka akan digunakan dan dapat memperkuat kepercayaan sehingga investasi yang dibuat menjadi lebih besar karena tingkat kepercayaan investor meningkat atau resiko ketidak pastian menjadi lebih mudah dikendalikan.

Sedangkan pada investor jangka panjang yang seharusnya merupakan fokus dari laporan terintegrasi, hasil eksperimen ini masih belum dapat membuktikan bahwa laporan terintegrasi dengan konektivitas tinggi akan lebih direspon oleh investor jangka panjang. Hal ini bisa disebabkan karena investor adalah investor non profesional yang pada umumnya berorientasi jangka pendek, investor yang berorientasi jangka panjang dipasar modal umumnya adalah investor institusional atau investor profesional. Selanjutnya hasil yang menarik adalah keputusan investasi untuk investor jangka panjang memberikan rata-rata keputusan jumlah investasi yang hampir sama yaitu pada besaran sekitar Rp5.000.000,dari kisaran 0 sampai Rp10.000.000 baik untuk laporan terintegrasi yang terkoneksi tinggi, maupun rendah. Hasil eksperimen ini dapat menggambarkan bahwa perilaku investor non profesional dalam berinvestasi pada tingkat moderat, dalam arti tidak berani berinvestasi secara maksimal, hal ini bisa dikarenakan tingkat kepercayaan dengan informasi yang ada berada pada level moderat.

Laporan terintegrasi adalah kompleks karena menyajikan informasi yang komprehensif, berupa strategi, model bisnis, kinerja perusahaan, outlook, sehingga pengambilan keputusan yang didasarkan pada laporan ini dapat menunjukkan hasil keputusan yang berbeda, karena bias kognisi. Kompleksitas informasi akuntansi mempengaruhi kemampuan individu mengintegrasikan informasi untuk pengambilan keputusan (Stocks dan Harrell, 1995).

\section{SIMPULAN DAN SARAN Simpulan}

Eksperimen ini menyajikan bukti empiris bahwa investor non profesional yang menggunakan laporan terintegrasi dengan konektivitas tinggi akan lebih besar keputusan rata-rata jumlah investasinya dibandingkan investor non profesional yang menggunakan laporan terintegrasi yang terkoneksi rendah. Hasil ini menunjukkan bahwa laporan terintegrasi yang terkoneksi tinggi memiliki kemanfaatan-keputusan yang lebih tinggi, dan riset ini konsisten dengan hasil penelitian Zhou et al. (2017). Eksperimen ini memenuhi teori kemanfaatan-keputusan (Staubus, 2013), yang menyatakan bahwa investor akan bereaksi ke arah yang diprediksi atas informasi yang diperoleh, apakah positif atau negatif tergantung kandungan informasi yang disampaikan apakah good news atau bad news.

Terdapat efek interaksi prinsip konektivitas <IR> dengan time horizon investasi pada keputusan jumlah investasi oleh investor non profesional. Laporan terintegrasi lebih menekankan pada investor jangka panjang karena laporan terintegrasi menginformasikan pemikiran terintegrasi dalam pengelolaan dan pelaporan perusahaan. Perusahaan yang memiliki investor berdedikasi dan berorientasi jangka panjang lebih berminat menyajikan laporan terintegrasi (Serafeim, 2015).

Eksperimen ini belum mampu membuktikan efek interaksi antara konektivitas $<\mathrm{IR}>$ tinggi dan time horizon panjang akan lebih besar dampaknya pada keputusan jumlah investasi dibandingkan dengan konektivitas <IR $>$ rendah dan time horizon investasi pendek. Efek interaksi ini dapat signifikan justru hanya pada investor dengan time horizon jangka pendek dan laporan terkoneksi tinggi lebih besar jumlah keputusan investasinya, dibandingkan dengan investor dengan time horizon pendek dan laporan terintegrasi terkoneksi rendah. Argumentasinya adalah investor jangka pendek fokus pada informasi keuangan, dan tidak pada kinerja non keuangan, serta tidak fokus pada aspek keberlanjutan jangka panjang, tetapi apabila informasi non keuangan tersaji dengan mudah dan dapat dipahami atau unsur readability terpenuhi, 
maka investor jangka pendek akan menggunakannya dalam pengambilan keputusan. Kontribusi dari eksperimen ini ialah, menambah pembuktian kemanfaatan keputusan dari laporan terintegrasi, melengkapi penelitian archaival yang memiliki kelemahan dalam hal efek kausalitas dan ketersediaan data pada awal tahap pengembangan suatu praktek akuntansi, memenuhi tantangan perlunya penelitian prinsip konektivitas (IIRC, 2017; Zhou et al., 2017) dan memenuhi perlunya penelitian ekspeimen dengan menekankan pada keputusan individual yang masih sedikit atas praktek <IR> (Rinaldi et al., 2018; Velte dan Stawinoga, 2017; Villiers et al., 2016).

\section{Saran}

Desain eksperimen dalam penelitian ini untuk perlakuan terhadap konektivitas hanya memperhatikan konektivitas antar waktu, konektivitas antar elemen, namun tidak memperhatikan konektivitas dengan pengguna karena dalam desain penelitian ini tidak menggunakan teknologi informasi online. Konteks adalah pada kinerja keuangan sama dengan rata-rata industri, dan kinerja non keuangan sangat tinggi dari rata-rata industri, tidak memperhatikan konteks yang positif maupun yang negatif. Elemen dalam laporan terintegrasi tidak mencakup seluruh elemen yang disarankan kerangka konseptual <IR>. Partisipan dalam desain eksperimen ini menggunakan surrogate mahasiswa akuntansi dimana memiliki kelebihan namun juga memiliki keterbatasan.

Partisipan dalam eksperimen ini tidak diberikan reward ataupun punishment sehingga keputusan yang diberikan tidak memiliki dampak langsung kepada subyek tersebut.

\section{DAFTAR PUSTAKA}

Adams, S., dan R. Simnett, 2011. Integrated Reporting: An opportunity for Australia's not-for-profit sector. Australian Accounting Review 21(3): 292-301.
Adhariani, D., dan C. de Villiers. 2019. Integrated reporting: perspectives of corporate report preparers and other stakeholders. Sustainability Accounting, Management and Policy Journal 10(1): 126-156.

Haji, A.A., dan M. Anifowose 2016. The trend of integrated reporting practice in South Africa: ceremonial or substantive? Sustainability Accounting, Management and Policy Journal 7(2): 190-224.

Arnold, M., A. Bassen, dan R. Frank 2018. Timing effects of corporate social responsibility disclosure: an experimental study with investment professionals. Journal of sustainable finance $\mathcal{E}$ investment 8(1): 45-71.

Baboukardos, D., dan G. Rimmel 2016. Value relevance of accounting information under an integrated reporting approach: A research note. Journal of Accounting and Public Policy 35(4): 437452.

Barth, M. E., S. F. Cahan, L. Chen, dan E. R. Venter 2016. The economic consequences associated with integrated report quality: early evidence from a mandatory setting. University of Pretoria, unpublished working paper.

Bernardi, C., dan A. W. Stark 2018. Environmental, social and governance disclosure, integrated reporting, and the accuracy of analyst forecasts. The British Accounting Review 50(1): 16-31.

Camilleri, M. A. 2017. The integrated reporting of financial, social and sustainability capitals: a critical review and appraisal. International Journal of Sustainable Society 9(4): 311-326.

Cheng, M. M., W. J. Green, dan J. C. W. Ko 2014. The impact of strategic relevance and assurance of sustainability indicators on investors' decisions. Auditing: A Journal of Practice \& Theory 34(1): 131162.

Dong, L. 2017. Understanding investors' reliance on disclosures of nonfinancial information and mitigating mecha- 
nisms for underreliance. Accounting and Business Research 47(4): 431-454.

Dumay, J., C. Bernardi, J. Guthrie, dan M. La Torre 2017. Barriers to implementing the International Integrated Reporting Framework: A contemporary academic perspective. Meditari Accountancy Research 25(4): 461-480.

Eccles, R. G., dan M. P. Krzus 2010. One report: Integrated reporting for a sustainable strategy: John Wiley dan Sons.

Eccles, R. G., M. P. Krzus, dan C. Solano 2019. A Comparative Analysis of Integrated Reporting in Ten Countries. Available at SSRN.

Feng, T., L. Cummings, dan D. Tweedie 2017. Exploring integrated thinking in integrated reporting-an exploratory study in Australia. Journal of Intellectual Capital 18(2): 330-353.

García-Sánchez, I. M., dan L. NogueraGámez 2017. Integrated reporting and stakeholder engagement: The effect on information asymmetry. Corporate Social Responsibility and Environmental Management 24(5): 395-413.

Green, W. J., dan M. M. Cheng 2019. Materiality judgments in an integrated reporting setting: The effect of strategic relevance and strategy map. Accounting, Organizations and Society 73: 1-14.

GRI. 2013. The sustainability content of integrated reports a survey of pioneers. In Research and Development Series (Ed.). Amsterdam.

Gunarathne, N., dan S. Senaratne 2017. Diffusion of integrated reporting in an emerging South Asian (SAARC) nation. Managerial Auditing Journal 32(4/5): 524548.

Hair, J. F., W. C. Black, B. J. Babin, R. E. Anderson, dan R. L. Tatham 2006. Multivariate data analysis (6): Upper Saddle River, NJ: Pearson Prentice Hall.

IIRC. 2013. The International <IR $>$ Framework: IIRC.

IIRC. 2017. International <IR> Framework Implementation Feedback: IIRC.
Lee, K.-W., dan G. H.-H. Yeo 2016. The association between integrated reporting and firm valuation. Review of Quantitative Finance and Accounting 47(4): 1221-1250.

Libby, R., dan B. L. Lewis 1977. Human information processing research in accounting: The state of the art. Accounting, Organizations and Society 2(3): 245-268.

Liyanarachchi, G. A. 2007. Feasibility of using student subjects in accounting experiments: a review. Pacific Accounting Review 19(1): 47-67.

McEwen, R. A., dan M. J. Welsh 2001. The effect of bias on decision usefulness: A review of behavioral financial accounting research Advances in Accounting Behavioral Research (pp. 3-24): Emerald Group Publishing Limited.

Nahartyo, E. 2012. Desain dan Implementasi Riset Eksperimen. UPP STIM YKPN. Yogyakarta.

Pavlopoulos, A., C. Magnis, dan G. E. Iatridis 2017. Integrated reporting: Is it the last piece of the accounting disclosure puzzle? Journal of Multinational Financial Management 41: 23-46.

Rensburg, R., dan E. Botha 2014. Is Integrated Reporting the silver bullet of financial communication? A stakeholder perspective from South Africa. Public Relations Review 40(2): 144-152.

Rinaldi, L., J. Unerman, dan C. De Villiers 2018. Evaluating the integrated reporting journey: insights, gaps and agendas for future research. Accounting, Auditing \& Accountability Journal 31(5): 1294-1318.

Rivera-Arrubla, Y. A., A. Zorio-Grima, dan M. A. García-Benau. 2017. Integrated reports: disclosure level and explanatory factors. Social Responsibility Journal 13(1): 155-176.

Serafeim, G. 2015. Integrated reporting and investor clientele. Journal of Applied Corporate Finance 27(2) 34-51.

Silvestri, A., S. Veltri, A. Venturelli, dan S. Petruzzelli 2017. A research template to 
evaluate the degree of accountability of integrated reporting: a case study. Meditari Accountancy Research 25(4): 675704.

Slack, R., dan I. Tsalavoutas 2018. Integrated Reporting decision usefulness: mainstream equity market views. Paper presented at the Accounting Forum.

Staubus, G. J. 2010. Accounting, accountability, auditing, and financial scandals over the centuries. Available at SSRN 1733229 .

Staubus, G. J. 2013. The decision usefulness theory of accounting: A limited history: Routledge.

Stocks, M. H., dan A. Harrell 1995. The impact of an increase in accounting information level on the judgment quality of individuals and groups. Accounting, Organizations and Society 20(7-8): 685-700.

Velte, P., dan M. Stawinoga 2017. Integrated reporting: The current state of empirical research, limitations and future research implications. Journal of Management Control 28(3): 275-320.

Villiers, C., E. R. Venter, dan P.-C. K. Hsiao 2016. Integrated reporting: background, measurement issues, approaches and an agenda for future research. Accounting $\mathcal{E}$ Finance.

Zhou, S., R. Simnett, dan W. Green 2017. Does integrated reporting matter to the capital market? Abacus 53(1): 94-132. 